CENTRE FOR ABORIGINAL ECONOMIC POLICY RESEARCH

\title{
Generational Change, Learning and Remote Australian Indigenous Youth
}

I. Kral

CAEPR WORKING PAPER No. $68 / 2010$

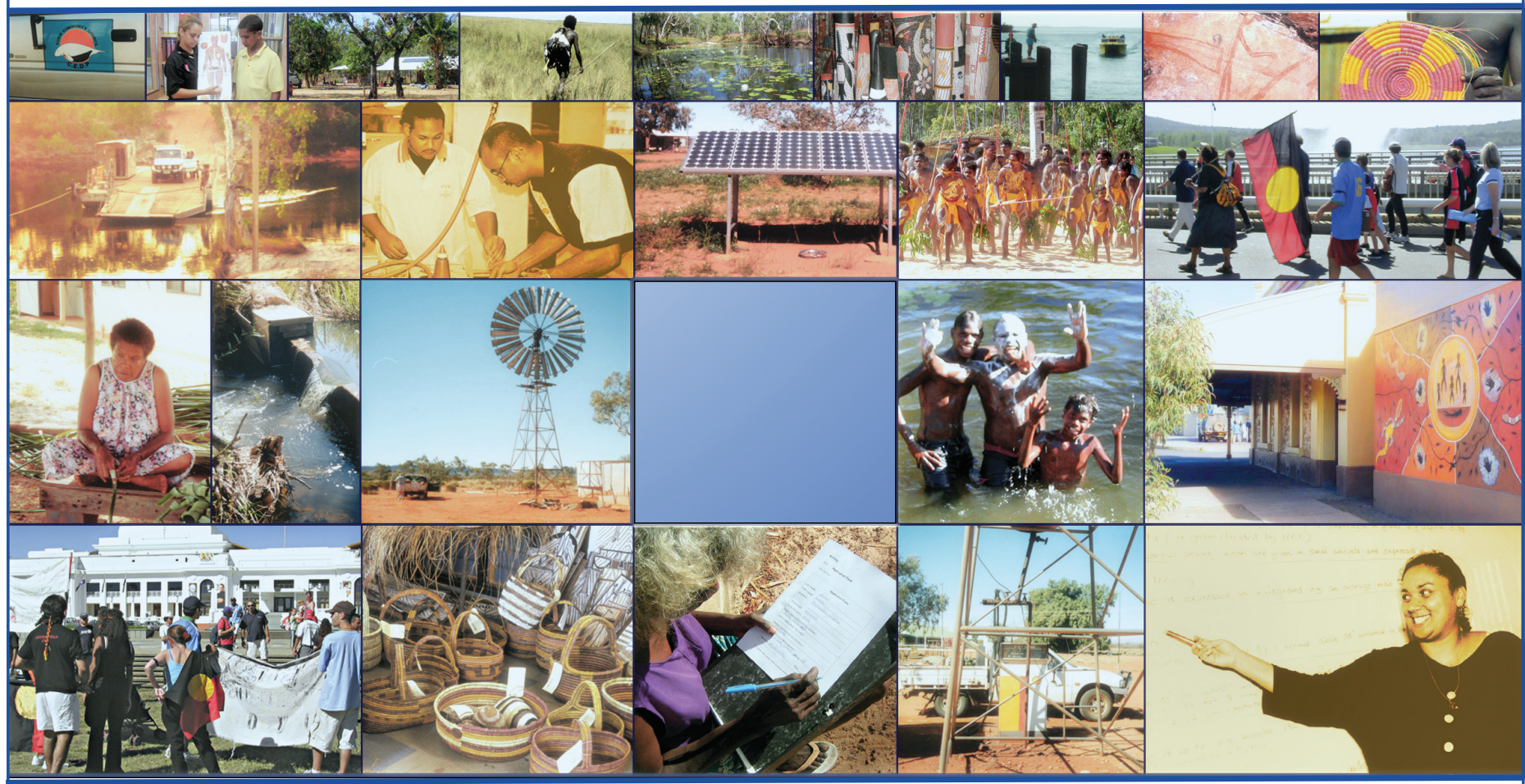




\section{SERIES NOTE}

The Centre for Aboriginal Economic Policy Research (CAEPR) was established at The Australian National University (ANU) in April 1990. Since 1 January 2010, CAEPR has operated as an academic unit within the Research School of Social Sciences in the ANU's College of Arts and Social Sciences. The Centre is funded from a variety of sources including the ANU, Australian Research Council, industry and philanthropic partners, the Department of Families, Housing, Community Services and Indigenous Affairs, and State and Territory governments.

CAEPR's principal objective is to undertake high-quality, independent research that will assist in furthering the social and economic development and empowerment of Aboriginal and Torres Strait Islander people throughout Australia. Its aim is combine academic and teaching excellence on Indigenous economic and social development and public policy with realism, objectivity and relevance.

CAEPR is currently Australia's major social science research centre focusing on Indigenous economic and social policy from a national perspective. The Centre's publications, which include the CAEPR Working Paper series established in 1999, aim to report on Indigenous circumstance, inform public debate, examine government policy, and influence policy formulation.

Working Papers are often work-in-progress reports and are produced for rapid distribution to enable widespread discussion and comment. They are available in electronic format only for free download from CAEPR's website:

$$
<\text { www.anu.edu.au/caepr/> }
$$

Enquiries may be directed to:

The Centre for Aboriginal Economic Policy Research

Hanna Neumann Building \#21

The Australian National University

Canberra ACT 0200

Telephone 02-6125 8211

Facsimile 02-61259730

As with all CAEPR publications, the views expressed in this Working Paper are those of the author(s) and do not reflect any official CAEPR position.

Professor John Taylor Director, CAEPR

Research School of Social Sciences

College of Arts \& Social Sciences

The Australian National University

May 2010

Cover page images courtesy of the Australian Institute of Aboriginal and Torres Strait Islander Studies and CAEPR staff members. 


\title{
Generational change, learning and remote Australian Indigenous youth
}

\author{
I. Kral
}

Inge Kral is a Post-Doctoral Fellow at the Centre for Aboriginal Economic Policy Research, Research School of Social Sciences, College of Arts and Social Sciences, The Australian National University, Canberra.

\begin{abstract}
In remote Indigenous Australia the typical mainstream youth transition from school to employment does not match the reality of community life, where traditional cultural schemas underpin the practice of everyday life and the construction of social identity. Although the developmental trajectory of the current generation of Indigenous youth has diverged from cultural norms, the introduced western trajectory of institutional learning leading to labour market employment does not yet offer a substitute paradigm. I argue that if young people are to become competent, mature adults able to shape their own futures and the economic and social viability of their communities, then attention will need to be paid, not only to institutional education and training pathways, but also to other approaches to learning. Such alternate pathways can contribute to the formation of a positive sense of self, strong cultural identities and the learning and literacy skills needed to shape Indigenous futures. This paper uses research from remote central and northern Australia to explore community-based approaches to youth learning and cultural production.
\end{abstract}

Keywords: Indigenous youth culture, cultural transition, Indigenous education, employment, lifespan learning

\section{ACKNOWLEDGEMENTS}

This research is funded through a three year (2007-10) Australian Research Council Linkage Project between the Centre for Aboriginal Economic Policy Research (CAEPR) at The Australian National University and The Fred Hollows Foundation, a philanthropic organisation. Other research partners include Ngaanyatjarra Media (Western Australia), Northern Territory Library, Ngapartji Ngapartji intergenerational language and arts project, Djilpin Arts Project, and the Warlpiri Education and Training Trust (all Northern Territory). This article draws on some material from my unpublished anthropology PhD thesis 'Writing words-right way! Literacy and social practice in the Ngaanyatjarra Lands' completed at The Australian National University in 2007. Most of the material is drawn from the 'Lifespan learning and literacy for young adults in remote Indigenous communities' Australian Research Council Linkage Project.

I would particularly like to thank Jenny Green, David Brooks, Shirley Brice Heath and Jerry Schwab for the insights and comments that have contributed to the development of the ideas in this paper. Additionally I wish to thank all the young people who have contributed their time and ideas over a number of years in various remote Aboriginal communities, most especially Jasmine Lawson, Delvina Lawson, Kresna Cameron, Shane White, Maxwell Tasman, Natalie O'Toole, Chris Reid, Nathan Brown and Revonna Urban. Finally, thank you to Hilary Bek and John Hughes at CAEPR for editorial and layout assistance. 


\section{CONTENTS}

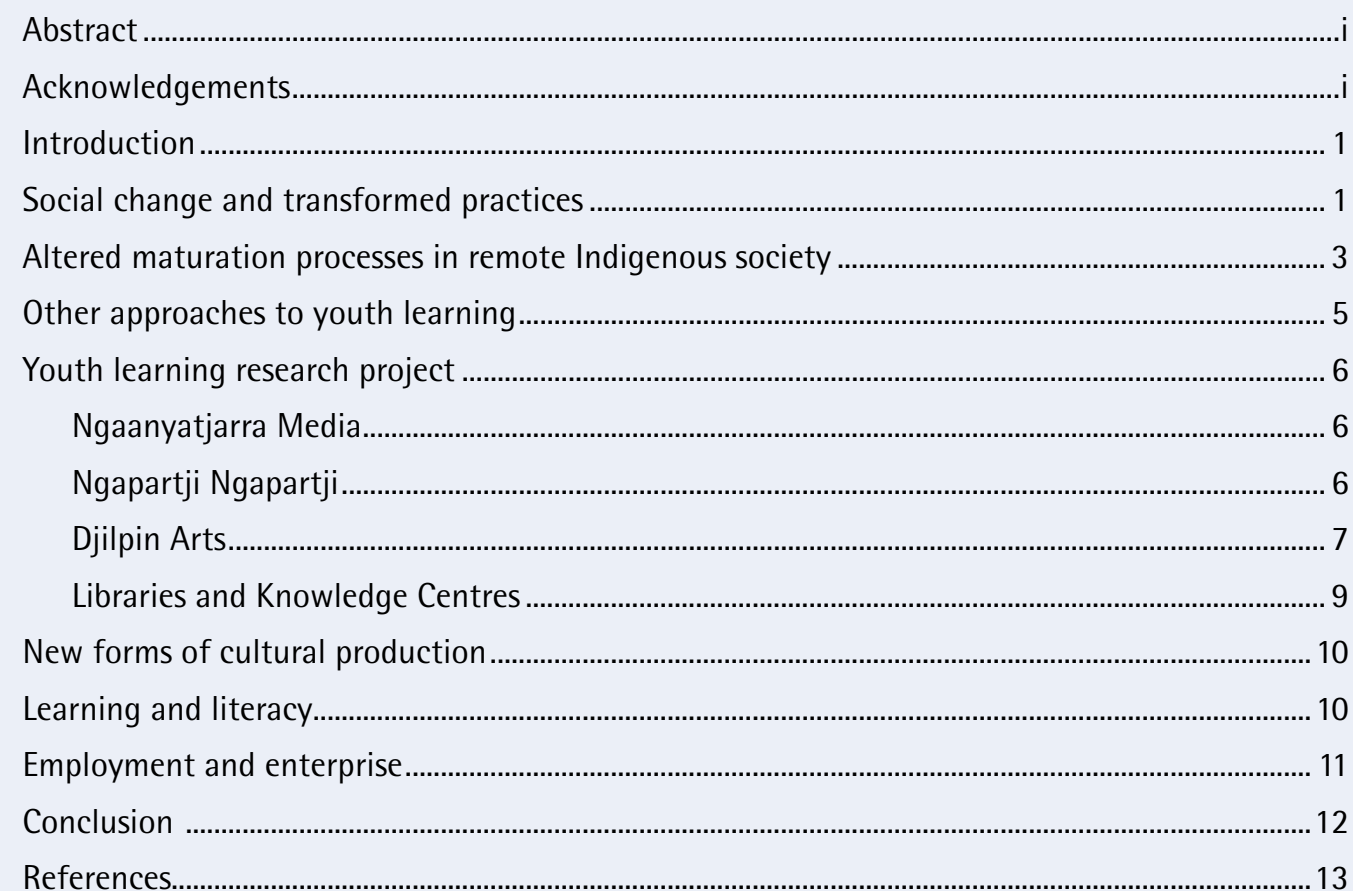

\section{FIGURES}

Fig. 1. Youth learning research project sites, 2007-10 .................................................................... 6

Fig. 2. Revonna Urban, Senior Arts Worker, Ghunmarn Culture Centre, Beswick.............................. 8

Fig. 3. Shane White, Media Worker, Lajamanu Library and Knowledge Centre, interviewing Jerry Jangala 


\section{INTRODUCTION}

A dominant narrative of failure portrays Indigenous youth from remote Australian communities entering adulthood illiterate and unemployable due to poor school attendance or low retention rates in the secondary years. To counter this, public and policy discourse promotes the transition from school to training and employment in the 'real economy' (Pearson 2000) as the singular pathway to realising future opportunities for remote Indigenous youth:

A job is the key to social and economic progress. A job delivers self-esteem and the means to get ahead in life (Commonwealth of Australia 2008).

This perspective does not, however, take sufficient account of the culture-specific logic that underpins the individual pursuit of credentials in mainstream western society, and is contingent upon an assumed and shared understanding of the normative logic of a sequenced pathway. In most mainstream western contexts, families and social institutions provide specific guidelines concerning the role expectations and behaviours of adolescents and youth are socialised into an individual trajectory of credentialisation leading to employment outcomes (Burton et al. 1996: 397). However, this 'normal biography' (Smyth \&t Hattam 2004) for the transition from adolescence to adulthood is problematic for youth in some sectors of western society who 'fail' to successfully make this transition (Bottrell \& Armstrong 2007; Willis 1977; Wyn \& Woodman 2006). In the remote Indigenous context this transition is even more problematic when mainstream credentialing - that is delayed gratification for a future employment reward-is not necessarily perceived as a prerequisite for a fulfilling life, as other socio-cultural schemas underpin the practice of everyday life and the construction of social identity.

In this paper I seek not only to demonstrate that the introduced western cultural process of schooling and the transition to wage labour employment does not have an assumed normative logic in the remote Indigenous world, but also to show how rapid social change over recent generations has impacted on the traditional processes of youth socialisation, maturation and learning for adult life. I use a 'practice' approach drawn from sociology and anthropology (Berger \& Luckmann 1975 [1966]; Bourdieu 1977; de Certeau 1984; Ortner 1984) to explore the notion of transformed practice. I describe how in many remote Indigenous communities in central and northern Australia, the current youth generation may be only the second, third or fourth generation to experience introduced institutional learning, and thus the sequenced pathway from schooling to employment is not yet a taken for granted practice. In this context schooling as a cultural process may not make the same sense as it does in mainstream, middleclass Australian families, because different social meanings and cultural practices are still attached to the adolescent maturation period.

If a mismatch exists between linear learning trajectories that propel youth towards mainstream employment outcomes and the social and cultural reality for many Indigenous youth, then a variety of approaches to attaining successful outcomes and youth transitions are required. I use research from a current project exploring youth learning in non-formal contexts to consider different pathways to successful futures, and propose that if the domains of youth learning remain focused solely on formal education then we may not see the potential that resides in other modes of learning for remote Indigenous youth.

\section{SOCIAL CHANGE AND TRANSFORMED PRACTICES}

For many remote Indigenous people in central and northern Australia the intergenerational understanding of schooling-and the connection to labour market employment and the cash economy-is still superficial. The transition from a nomadic hunter-gatherer existence to a sedentary 'community' lifestyle came relatively late, and only after people walked into or were forced into missions, settlements and towns in the early 
to mid-twentieth century. In certain locations contact with Anglo-Australian settler society was delayed: some very remote groups continued a hunter-gatherer existence until the 1950s in parts of Arnhem Land (Altman 2007) and the 1960s in the Western Desert regions of central Australia (Davenport, Johnson and Yuwali 2005; Kral 2007b). Traditional cultural dispositions and norms began altering only a few generations ago when people started adapting to European social and institutional practices. Once the encounter with the nation state commenced, however, people became 'habitualized' (Berger \& Luckmann 1975 [1966]) into the paradigm of school, training and work encountered on missions, stations and settlements, and new markers developed for the adolescent transition to adulthood.

In the 1960s a national policy of assimilation was introduced to more rapidly integrate Indigenous people into mainstream Australia. By the 1970s, however, a confluence of factors-including a decline in the rural economy, access to alcohol and the introduction of Unemployment Benefits-meant that the trajectory for many who had been habituated into an expectation of advancement and employment through schooling and 'tutored assimilation' (Kral 2007b) had altered, and the optimism associated with employment opportunities for remote youth started to dissipate. According to historian Tim Rowse (1998: 114), the realisation of the goal of integration into the mainstream economy necessitated moving remote people 'from rations to cash' through the provision of equality of access to social security benefits and inclusion in normal industrial awards as 'indisputable entitlements'. Contemporaneously with remote people acquiring European norms and practices, they were also making the profound transition from operating within a hunter-gatherer economy to participation in the cash economy.

Prior to the 1950s, few remote people had direct experience of using cash. Only in 1959 did amendments to the Commonwealth Social Services Act finally allow 'nomadic' Aborigines access to welfare benefits (i.e. child endowment and the pension) (Rowse 1998: 133). However, payments could only be paid directly to an individual if that person could demonstrate an ability to handle money wisely (Sanders 1986: 99). Significantly, despite the 1959 amendments to the Act, direct payment of full cash welfare benefits to individuals in some remote locations commenced as late as 1971 (Kral 2007b). Equal wages for Indigenous pastoral workers were finally awarded only in 1968.

Ironically, the requirement to pay equal wages forced many Indigenous workers and their families in remote regions off pastoral stations and into the newly established government settlements. Indigenous labour was used to build the new settlements as a deliberate policy to instil in people a realisation of the necessity of paid employment as a 'normal' way of life (Rowse 1998: 172). Employment and governance roles in Indigenous communities and organisations commenced from the mid-1970s under a new national

CDEP:

Community

Development

Employment

Projects policy of self-determination. In remote locations this was facilitated by the Community Development Employment Projects (CDEP) scheme, designed specifically for remote circumstances where there was no market economy (Coombs 1977).

I have elsewhere described the short history of Indigenous education in remote regions (Kral 2007a, 2007b). In the Northern Territory and Western Australia, government responsibility for the education of Indigenous people commenced only in the 1950s. Prior to the introduction of government schooling, most remote Indigenous children were either still nomadic and receiving no western schooling, or were being educated in mission schools. In some Northern Territory communities government schooling did not start until the 1970s or later, and access to secondary education remains sporadic to the present day. Up to the 1970s, adults who had acquired literacy read and wrote according to their emerging roles and identities within the expanding domains of western-influenced practice. At that time there was a correlation between the basic literacy skills that people had acquired in school and the unskilled employment requirements of the time. In remote regions this was primarily stock work for men and domestic work for women, and later community development projects (including education and health roles) under CDEP. However since the 1970s, massive technological changes and encroaching globalisation (Appadurai 1996; Giddens 1991) have 
dramatically altered the expectations of employment all over the world. Australia responded to the new requirement for higher employee skills and competencies by introducing the National Training Reform Agenda in the late 1980s (Baker \& Sloan 1995). This has impacted on training and employment in remote Australia, where the employment of Indigenous workers is increasingly contingent upon the attainment of nationally accredited vocational training qualifications.

Thus, the generation of remote Indigenous youth who came into young adulthood in the 1980s and 1990s encountered a growing mismatch between the expectations of what could be done with basic literacy skills and the increasing demand for more complex vocationally-oriented literacy proficiency. Employment opportunities that had previously been available for adults with minimal literacy competence diminished as the expectations of literate and technical competence accelerated. As a consequence, the post-1980s adult generation appeared more il-literate than previous generations. More recently a deficit perspective has been reinforced by the media emphasis on the 'failure' of English as a second language speaking Indigenous students to meet the National Assessment Program-Literacy and Numeracy (NAPLAN) benchmark standards.

In summary, it can be surmised that the immediate post-encounter generation took on the European world as a logical system within their own cultural framework of non-change, and incorporated new paradigms into everyday practice. Subsequently, however, remote groups were to experience rapid waves of change. In response, many people began to experience a diminishing sense of certainty, predictability and control as introduced cultural processes clashed with pre-existing social frameworks. Anthropologists posit, however, that no matter how adept remote Indigenous people have been at taking on European practices and institutional norms, just under the surface key cultural processes remain to impact on the present (Austin-Broos 2003; Burbank 2006). In fact the world view, social practices, language and culture of the Indigenous 'domain' have prevailed, underpinned by the immutable authority of traditional Indigenous Law (von Sturmer 1984).

\section{ALTERED MATURATION PROCESSES IN REMOTE INDIGENOUS SOCIETY}

Modernity has ushered in a break in the traditional maturational cycle and this has put pressure on the identity formation processes of remote Indigenous youth. Western schooling introduced a life-span division between childhood and adulthood that has shaped the hitherto unknown social category of 'adolescence' in traditional Indigenous society. Indeed, prior to the twentieth century 'adolescence' as a developmental period was also unknown and virtually inconceivable in western culture (James 1993). Adolescence as a concept appeared by the end of the nineteenth century in tandem with the transformation from an agricultural orientation to an urban industrial one, and so-called 'youth culture' peer groups began to emerge (Erickson 1968; Mannheim 1952; Rogoff 2003).

In traditional Indigenous society a division between childhood and adulthood was evident in physical changes further marked by gender-specific social activities and ceremonies. Western schooling institutionalised the close proximity of mixed gender, age-graded peer cohorts, rather than multi-generational, affiliated groupings. With adolescent cohorts spending substantial periods of time together, traditional marriage patterns started to alter. With schooling compulsory for the ambiguous new cultural category of 'adolescents', a disjuncture between traditional expectations of maturation and the school's expectation of 'normative' developmental stages emerged, and childhood has been extended beyond normal cultural limits (Kral 2007b). This dilemma is being played out in the low attendance and retention rates for both males and females in the secondary years. 
Still today, in the Western Desert region of central Australia, the maturation cycle for males incorporates a ceremonial transition, or rite of passage, from childhood into manhood wherein adolescent males are transformed into 'men'-even though adult authority may not be realised until a later stage (Brooks forthcoming; Fietz 2008). Prior to contact with European society, going through the stages of the 'Law' was a time-consuming imperative for young men, who experienced a long period of pre-marriage independence in which they went into the outside world to test themselves and assert autonomy. Accordingly, men tended not to marry until they were around 30, after they had completed lengthy initiation rites, whereas girls married around puberty (Myers 1986; Stanton 1983; Tonkinson 1974). Although 'going through the Law' remains a significant cultural process, the experience is no longer sufficiently enduring or robust to provide the full complement of skills required for contemporary social paradigms or life circumstances.

The impact of social change has been more disruptive for young men than for young women. Under contemporary conditions, adolescent males tend to drop out of school after passing through initiation ceremonies around the age of 14 or 15 . They have lost the period of premarital independence, are marrying younger and showing a greater tendency to spiral into substance abuse, anti-social behaviour and even incarceration. Australian researchers have explored the negative consequences of rapid social change, particularly for Indigenous males (Beresford \& Omaji 1996; Brady 1992; Robinson 1997). The western male trajectory of institutional learning leading to employment does not offer a substitute pathway that makes sense within remote Australian cultural paradigms, and consequently young men are struggling to find relevant identity formation processes. In contrast, young women are maintaining predictable cultural patterns of adolescent development associated with childbirth and motherhood.

Simultaneously, old forms of regulatory control such as the authority of senior men and notions of 'shame' have also fragmented. In the Western Desert, oral memory and the transmission of cultural knowledge and learning through the Law was critical to the maintenance of a regulatory framework that has bound culture over generations. Today, ceremonial activity ties kin into a system of reciprocal rights and obligations where the Law provides a set of socially sanctioned norms of conduct or rules that govern behaviour in the broader moral community. However, with the loss of the regulatory sanctions of the past, the old boundaries of obligation, responsibility and compulsion have become blurred. As a consequence, young people are, to a greater extent than ever before, asserting their autonomy and choosing how to spend their time. They are sensitive to parameters that infringe upon their autonomous sphere. This is leading to a propensity to walk away from school, training or employment when it has no meaning for them (unlike in the traditional past when bypassing learning through the Law had severe consequences). Accordingly, youth are spending little time in institutional learning environments and there is an engagement gap in communities in the out-of school and post-school years. With everyday life increasingly self-regulated, youth have larger amounts of discretionary leisure-time than ever before, and this can lead to boredom and antisocial behaviour. However, admonishing youth to stay at school and implementing punitive measures to deal with school non-attendance may not be a solution if experience shows them that schooling makes little appreciable difference to the quality of life and the factors that matter in the construction of a meaningful life.

Remote Indigenous communities have also witnessed the fragmentation of traditional language socialisation processes. Western institutional practices, values and expectations are replacing cultural learning, and schooling has reduced the time spent acquiring and using complex linguistic structures, routines and traditional speech styles. The discourse structures, verbal arts and stories of past generations are not being transmitted as they once were. Language plays a critical role in the 'construction of social identity' (Ochs 1993). With altered language socialisation practices and the predominance of English in the domains of education, employment and the media, adolescents are internalising the message that only western culture and English language have value. Meanwhile, their fragile Indigenous languages hover on the brink of endangerment and extinction (Australian Institute of Aboriginal and Torres Strait Islander Studies/ Federation of Aboriginal and Torres Strait Islander Languages 2005). 
Western socio-cultural practices have transformed Indigenous cultural processes in remote regions and this has contributed to the inexorable erosion of traditional maturation cycles and the diminution of prior rule-bound practices. The current generation of young adults has been unable to absorb many cues from their elders on how to deal with the new world, and so young people are having to figure out paradigms for contemporary living for themselves. Anthropologist Margaret Mead suggests that when there has been a profound break between the experiences of the old and the experiences of the young (as exemplified in the transitional upheaval from nomadism to contemporary community life within only a few generations) cultural transmission and socialisation patterns are challenged (Mead 1978 [1970]: 17). Sociologist Anthony Giddens notes how globalisation happened concomitantly with an 'acceleration' of the idea that humans can 'control nature' (Giddens 1991: 144). It can be speculated that modernity has wrought a schism in the remote Indigenous world view-where the traditional understanding that events are determined by the Dreaming or the Law and authority resides in the gerontocracy-has been challenged by the Western notion that individuals have choice and control but often within unpredictable and often incomprehensible contemporary parameters.

As I have outlined above, in remote Indigenous contexts the transition from school to training and employment is not yet a taken-for-granted cultural process. Youth socialisation practices and the processes of acquiring competencies for adult life have altered, yet the values, norms and dispositions that are transmitted intergenerationally remain linked to the Indigenous worldview and this is causing tension in the adolescent years. The developmental trajectory of this generation of young adults has diverged from cultural norms, yet the assumed normativity of the western adolescent developmental trajectory does not match the social, cultural or economic reality of remote community life. Mainstream policy proposes that schooling and vocational training offer the choices or opportunities required for successful Indigenous futures. I conjecture that in the remote Indigenous world there is deep uncertainty about what education is actually for (Kral \& Falk 2004). That is, youth participate in the everyday routines of schooling, but the linkages between schooling and the meaningful occupation of young people in the post-school years are weak (National Languages and Literacy Institute of Australia 1996).

\section{OTHER APPROACHES TO YOUTH LEARNING}

Internationally, researchers have started to focus on youth-based organisations as sites for non-formal learning (Fine et al. 2000; Vadeboncoeur 2006) and they have drawn on the theoretical ideas of 'out-ofschool' (Hull \& Schultz 2002) or 'situated' learning' (Gee 2004; Lave \& Wenger 1991). Projects or activities that excite and engage youth (and are additive to formal instruction) are being posited as learning environments (Heath \& Smyth 1999; McLaughlin, Irby \& Langman 1994) for the acquisition of myriad skills required for adult life, including literacy. In recent years literacy researchers have also used practice theory to view literacy not in terms of skills and competencies, but as an integral component of social events and cultural practices (Barton, Hamilton \& Ivanic 2000; Street 1993). Until now, such approaches have received little attention from educators and policy makers in Australia. In fact, research has rarely looked outside pedagogical settings in remote Indigenous contexts to document the non-school arenas of youth socialisation, learning and literacy practice.

\section{YOUTH LEARNING RESEARCH PROJECT}

In the final section of this paper I turn to a current research project exploring approaches to communitybased learning for young adults from remote communities. The Lifespan learning and literacy for young adults in remote Indigenous communities is a three year (2007-10) Australian Research Council Linkage Project between CAEPR at ANU and The Fred Hollows Foundation. This project is an ethnographic study 
Fig. 1. Youth learning research project sites, 2007-10

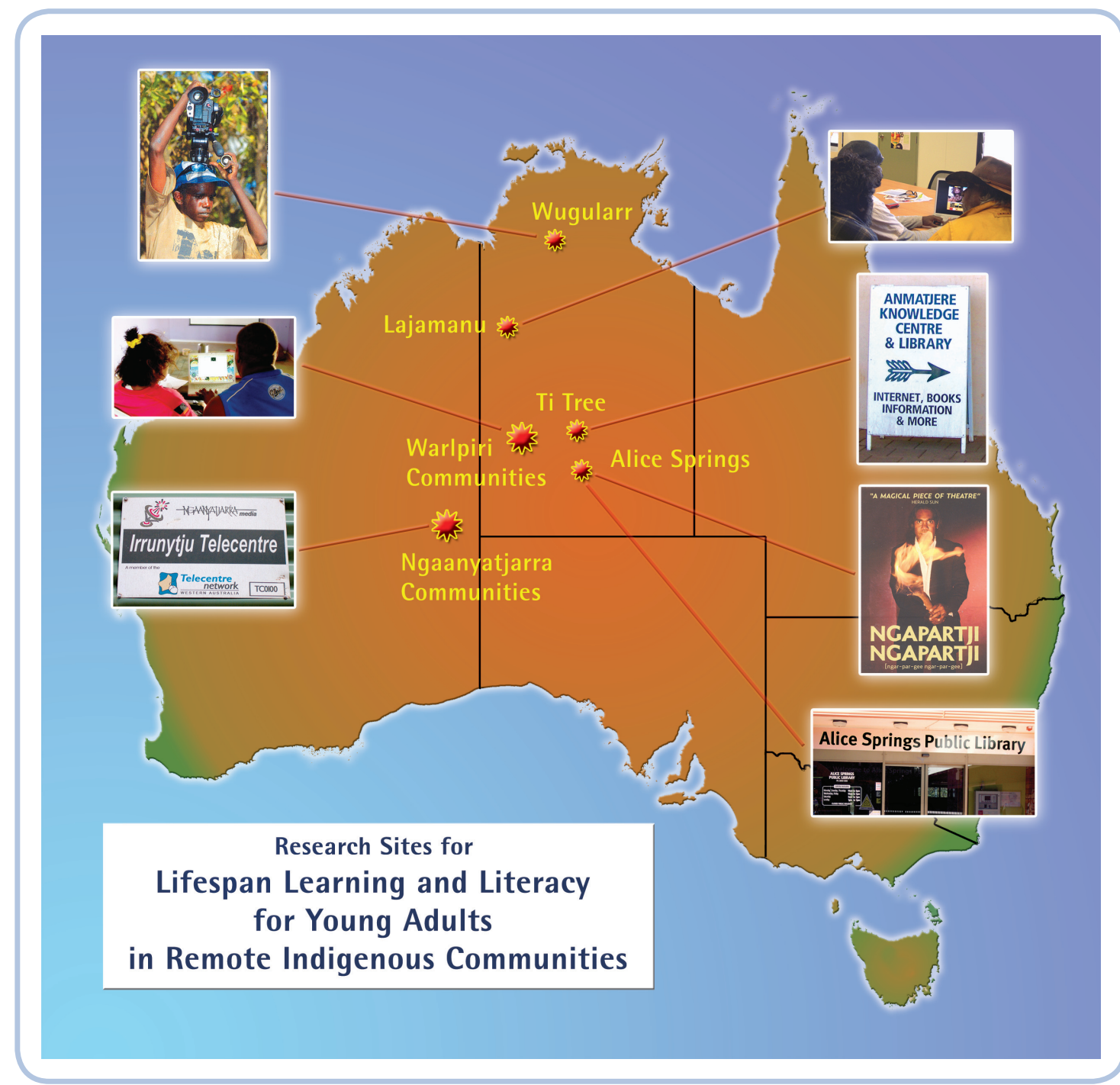

Source: Hughes and Kral, CAEPR.

of young Indigenous adults aged between 16 and 25, most of whom are early school leavers and have disengaged from formal education. These young adults are choosing to spend their discretionary leisuretime participating in learning and production-oriented multimedia, film-making, music production, digital archiving or arts-based projects. The project sites in the Northern Territory and Western Australia include music recording at Ngaanyatjarra Media, digital archiving at Libraries and Knowledge Centres, Ngapartji Ngapartji intergenerational arts project, Djilpin Arts youth media and arts project, and youth centres supported by the Warlpiri Education and Training Trust (see Fig. 1). The sites were chosen as exemplars of best practice learning environments that are attractive to youth and provide contexts for cultural production, language maintenance and the development of 'multimodal' literacies (Hull 2003; Kress 2003). I will briefly describe four of the project sites. 


\section{NGAANYATJARRA MEDIA}

Ngaanyatjarra Media (previously Irrunytju Media), was established at Wingellina community in remote Western Australia in 1992 and is responsible for media production and training across a wide region. It has promoted language, culture, music and stories through video, radio and multimedia production, and broadcasts in the three languages of the region: Pitjantjatjara, Ngaanyatjarra and Pintupi. It has also supported, through community telecentres, the provision of public access internet and computers containing information and applications that are meaningful to local people. In December 2007 short, informal training workshops in GarageBand-free music recording software available as part of the ilife suite on Macintosh computers-were held for young musicians. Members of local bands play instruments and perform in local festivals, but with GarageBand they are doing something different by adapting their musicality to the digital environment. Previously music recording was a long and arduous process predominantly controlled by nonIndigenous experts. Now young musicians have new control over digital recording and the whole process, including developing the text and artwork for the CD cover, can be done by young people locally, using the one computer and all within a short period of time. As a consequence, new roles have emerged for producers, artists, song writers, transcribers and translators, as well as musicians. In turn these local producers are training musicians in other communities. Young musicians are gaining status from having their music played at festivals and uploaded onto YouTube and MySpace social networking websites. The potential enterprise pathway of this nascent music industry is also being explored with CDs distributed for sale in urban music retail outlets.

\section{NGAPARTII NGAPARTJI}

The Ngapartji Ngapartji intergenerational language and arts project is based in Alice Springs and works with Pitjantjatjara community members who often reside in town camps. The project began in 2005 and involves community members of all ages in an online language teaching and preservation project, a professional theatre performance that tours nationally promoting indigenous culture and language, and a variety of workshops and projects based in both in Alice Springs and on remote communities. The Ngapartji Ngapartji project is underpinned by its commitment to language and culture maintenance and to facilitating learning through all aspects of its work. The project engages youth in ongoing learning and multimodal literacy activities through film-making, digital storytelling and recording project activities in Alice Springs, and film and song recording workshops in bush communities.

\section{DJILPIN ARTS}

Djilpin Arts is a community-owned arts organisation in the Kriol speaking community of Beswick (Wugularr) in the Top End of the Northern Territory. The project emphasises youth learning and enterprise development as priority areas. The focus for the arts organisation is the maintenance of cultural knowledge systems that are useful to people in the contemporary world. It has established a successful dance performancebased festival and tourism venture, an arts retail outlet and a youth media project. Young filmmakers have been trained to document the community arts and cultural activities. In these projects young people are given responsible roles where they are interacting with Indigenous and non-Indigenous mentors as well as filming and editing professional standard productions. Ghunmarn Culture Centre, which opened in May 2007 in a renovated community house, is the only arts centre in central and northern Australia employing young people in arts worker positions with high levels of responsibility (Fig. 2). There are two aspects to this enterprise, one is the employment of young women as arts workers and the other is a café and beauty products enterprise where young women make soap and other products using traditional bush plants and medicines. Here young women have a modern role that connects them with the knowledge and language of the past, allowing intergenerational links to be forged, while also meeting the requirements of the European Australian market for 'authentic' Indigenous products. 
Fig. 2. Revonna Urban, Senior Arts Worker, Ghunmarn Culture Centre, Beswick

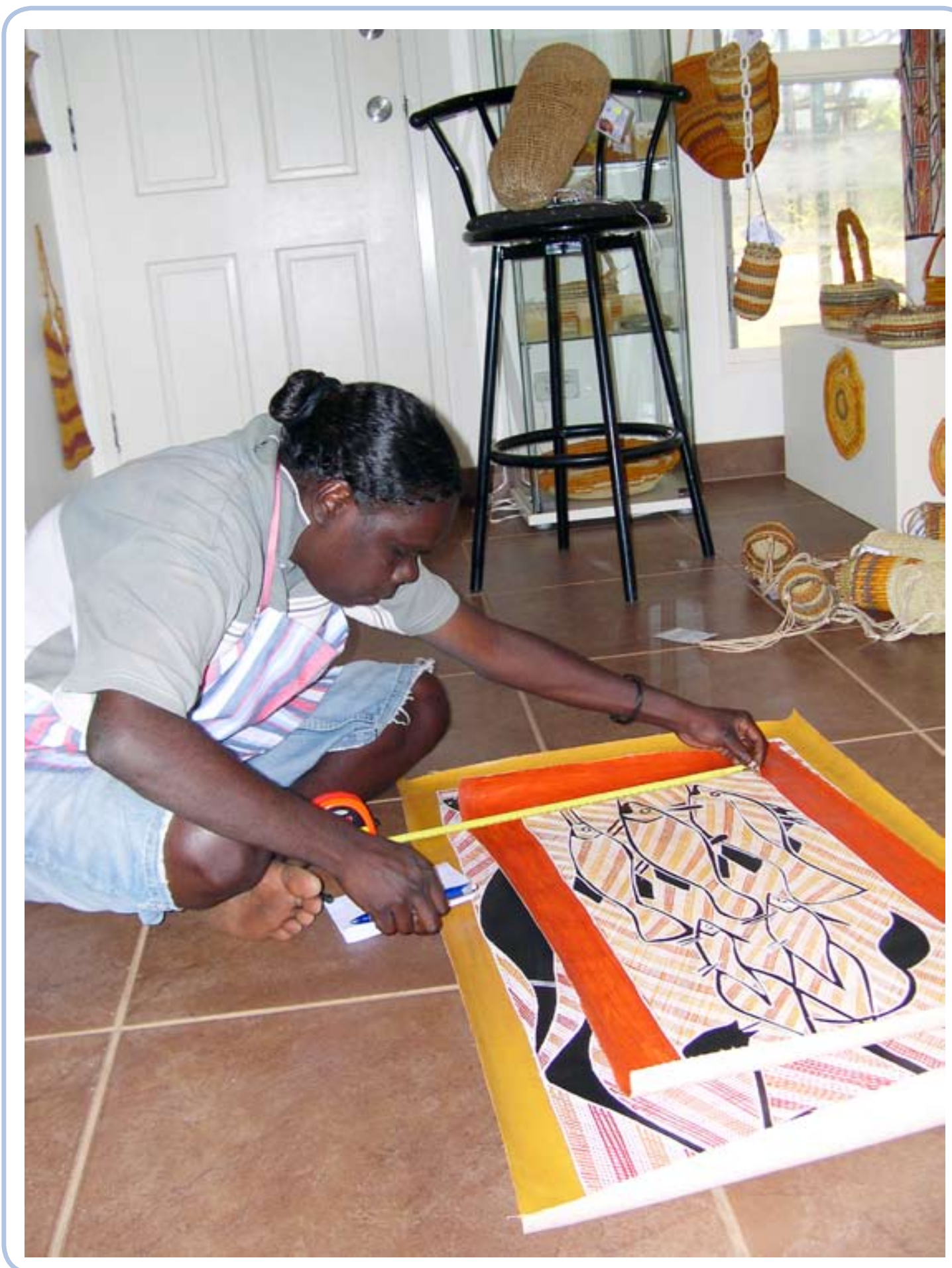

Source: Kral 2008. 
Fig. 3. Shane White, Media Worker, Lajamanu Library and Knowledge Centre, interviewing Jerry Jangala

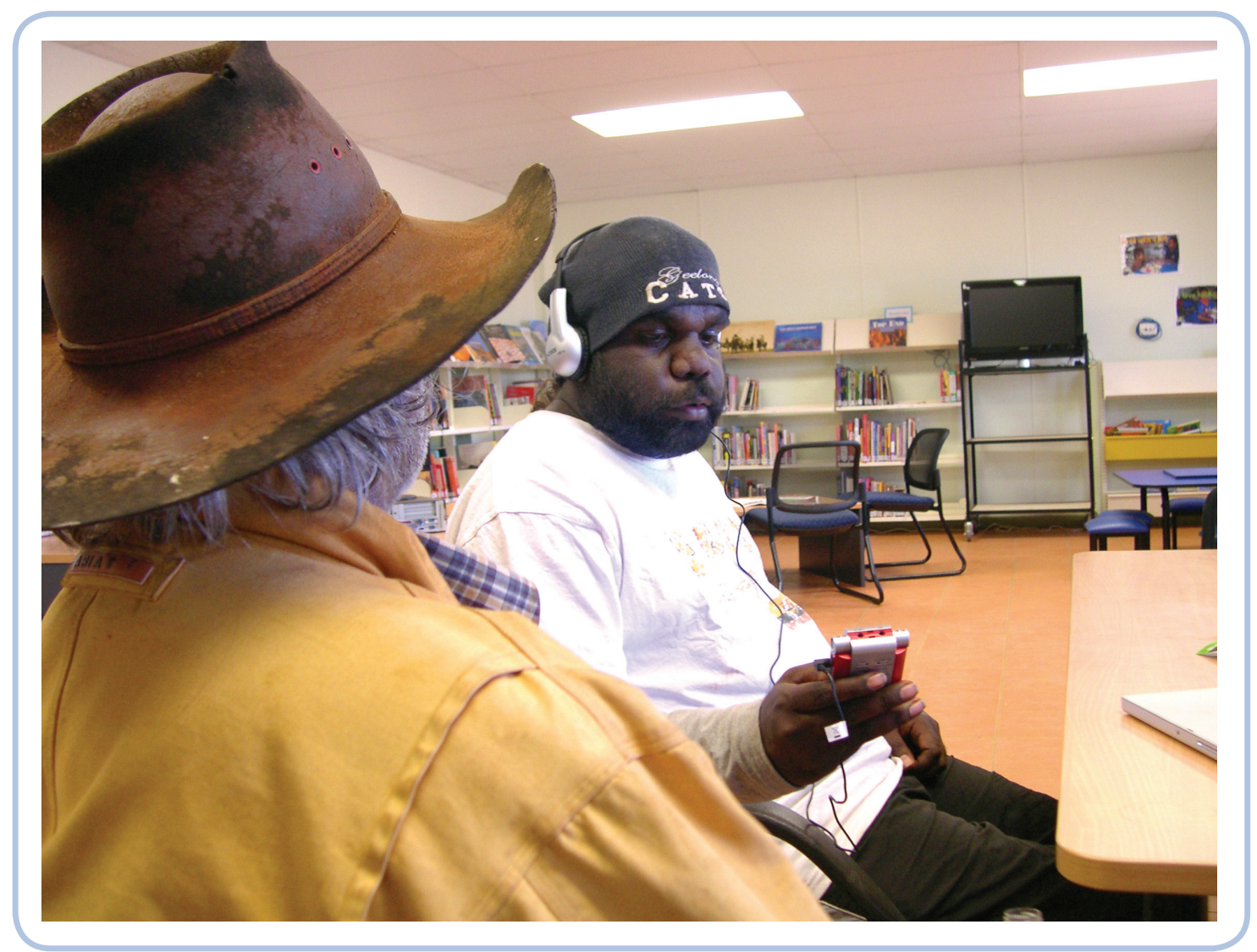

Source: Kral 2008.

\section{LIBRARIES AND KNOWLEDGE CENTRES}

The OurStory archival database has been introduced into Libraries and Knowledge Centres in remote communities by the Northern Territory Library Service. In the database, repatriated items are enriched with annotations and new material is included via the use of digital media technologies (Gibson 2007). In this way old materials are mixed with newly created content which is often produced by young people in the community who have had media training. Young people are responsible for archiving and documenting local community knowledge. They learn how to import media items, understand file formats and add metadata as they work with elders to record, transcribe and translate texts to create a localised database. At Lajamanu, a Warlpiri community in the Northern Territory, two young men who work in the Library and Knowledge Centre have made digital films with local musicians and cultural documentaries with elders (Fig. 3). The films are subtitled in Warlpiri or English, stored in the database or uploaded onto YouTube. This work is validated by elders who need young people to mediate between old knowledge and new technologies, and simultaneously young people are engaging in language and culture maintenance activities as the facilitators of digital media. 


\section{NEW FORMS OF CULTURAL PRODUCTION}

The grandparents of many of the young people in this study were born into a nomadic life where cultural production and reproduction was linked to hunting and gathering and traditional social and cultural practices, with little material culture. Now life is increasingly connected to mainstream practices, technology and a non-traditional lifestyle. Remoteness no longer isolates youth from broader cultural influences and they are exposed to more diverse socialisation networks than experienced by their elders. The current youth generation is exploring and internalising new and diverse 'intercultural arenas of social practice' to forge an emerging identity not based on models reproduced within cultural memory, but on a synthesised multiplicity of influences (Merlan 1998: 145). Youth today are seeking new ways of expressing a contemporary Indigenous identity: they are change agents, drawing on pre-existing knowledge and skills from the local community, but also seeking to know more about the outside world. They are infused with contemporary images and ways of being, and this affects every aspect of how they orient their daily life: how they dress, what they listen to and how they project their sense of self. And many, as evidenced in this research project, are successfully mediating between old knowledge and new technologies to create new forms of cultural production.

Over the last five years (as digital technology has been rolled out in remote contexts in the quest to bridge the digital divide) we have seen the rapid acquisition of digital media skills among the youth generation in tandem with an explosion of personal ownership of small, mobile digital media hardware (MP3 players, mobile phones, iPods, digital cameras, etc). Increasingly, communities also have broadband access. In the research sites many of the projects have tapped into digital media forms and technologies as a way of engaging young people in multimedia, multimodal practices in the non-school hours. In these sites, youth in the out-of-school and post-school years have access to activities, resources and mentors that stimulate the maintenance and development of oral and written communication skills, computer literacy, as well as business and marketing skills. With access to resources at the project sites, young people are becoming the controllers and producers of processes that generate unique resources, rather than the reproduction of models bounded by institutional parameters. Initial participation is generally unpaid, but youth are developing skills that often lead to participation in accredited training, and employment or enterprise generation.

This generation cannot replicate the traditional template set by their elders; instead they are seeking new ways of expressing a contemporary Indigenous identity. The research shows that they are forming the understandings, skills and competencies they require to enter young adulthood as bilingual, bicultural beings, drawing on the language and culture transmitted by their elders, but also transforming it. They are choosing to participate in these projects because the cultural production roles are in the domains of knowledge that matter to them-culture, arts, country, and new technologies, all within a framework of social relatedness. Significantly, they are doing this outside school or post-school training and so often remain invisible to many policy makers and government officials. The research indicates that when learning opportunities are provided in the projects described above, successful outcomes are being attained and young people are projecting positive futures.

\section{LEARNING AND LITERACY}

As discussed previously, institutional models of formal education are failing to attract, and hold onto, young learners in remote communities. This research has found that although young people may be walking away from mainstream models of schooling and training, they are not rejecting learning. Instead a lot of learning is taking place in a range of community-based domains. The case studies indicate that 
youth are engaging in projects where they have control over the space, time and resources to acquire and practice relevant, new skills, and where they have the freedom to explore and express their contemporary Indigenous identity. Projects that are oriented towards learning and production, rather than diversion from boredom and substance abuse, are attracting young people. Here learning is not based on a curriculum or a programmatic system, but integrated into and contextualised around real life in an environment that views young people as community resources, rather than problems. New skills are learned from older relatives, peers, and Indigenous and non-Indigenous experts, and competence is gained informally through observation, peer learning, trial and error, practice and interactions with mentors. Regular interactions with English-speaking mentors in a range of communicative contexts is leading to the development of new and complex syntactic and discursive structures, thus providing young speakers with an additional arena to acquire the linguistic and conceptual tools needed to move toward adult roles. Young people are experiencing non-directed learning, practicing that learning and producing meaningful cultural artefacts through a process of control, internal monitoring and self-evaluation. Individual specialisations are emerging and youth are setting high skill attainment levels for themselves.

Earlier I discussed how literacy practice in remote communities has mostly been associated with schooling. The shallow historical depth of schooling in remote communities, coupled with the fact that most adults tend to live in a world where reading or writing in any language is not integral to everyday communication, livelihood or recreation, means that few everyday social literacy practices have developed. Furthermore, homes and camps have not been resource-rich literacy environments (Bat 2005; Northern Territory Library 2008) and there has been minimal access to literacy artefacts in public spaces for self-directed, creative production in the discretionary leisure hours. Most noticeably however, with the increased access to digital technology we are seeing the rapid acquisition of technological and multimodal competence among the youth generation. We are witnessing a new wave of literacy activity as young people experiment with the production of multimodal texts in a manner that is forcing a rethink of assumptions about literacy in this domain. Where activities are tied to meaningful community projects, Indigenous youth are engaging as the mediators and facilitators of digital literacy in collaborative, participatory, intergenerational activities that positively affirm their contemporary Indigenous identity and their 'belonging-ness' to globalised youth culture.

\section{EMPLOYMENT AND ENTERPRISE}

Earlier I discussed how public and policy discourse promotes schooling, vocational training and employment in the 'real economy' as the assumed pathway to realising future opportunities for Indigenous youth. The research discussed here indicates that many young people do not foresee themselves leaving their communities to seek employment. For them, the future lies in social relatedness (maintaining connections to kin and country) and meaningful, productive engagement in the social and economic viability of their own communities. An alternative discourse in the Indigenous policy literature supports this view suggesting that participation in the 'cultural economy' or 'hybrid economy' (Altman 2007) and maintaining community viability may have more relevance, and thus more traction, than a trajectory of credentialisation leading to the future maturation of abstract employment outcomes. While it is understood that mainstream employment offers one pathway, another is a 'livelihoods' approach that builds the local economy, affirms Indigenous identity and provides a template of meaningful adult occupation for the next generation to replicate. In the projects described above, economic outcomes are being achieved. We are already seeing how new roles are being generated with youth employment opportunities opening up in arts and cultural centres, with media and music production, and the application of digital media skills to archival databases. These economic enterprises pivot around shared cultural belief systems and semiotic resources where both material and symbolic production is valued. In this 
way we are seeing remote Indigenous youth drawing from the traditional Indigenous context to become knowledge producers, but in transformed processes by making the connection between the local community context and a contemporary market economy.

\section{CONCLUSION}

In this paper I have suggested that while successive generations of children in remote Australia have participated, to a greater or lesser degree, in the everyday routines of schooling, the underlying western cultural assumptions associated with the pursuit of credentials for future abstract employment outcomes are not yet being transmitted as cultural processes. Although some Indigenous adolescents may succeed in the mainstream trajectory, for the majority-especially early school leavers-there is a significant engagement gap in the post-school years. Accordingly, if the domains of adolescent learning remain focused solely on formal education and training options, then we may not see the potential that resides in other forms of learning and youth socialisation. Therefore, in addition to mainstream models of employment, creative ways of visualising purposeful engagement, livelihoods and income generation are required to generate successful futures for remote Indigenous youth. Non-formal community-based learning environments such as the projects described above offer one such approach. 


\section{REFERENCES}

Australian Institute of Aboriginal and Torres Strait Islander Studies in association with the Federation of Aboriginal and Torres Strait Islander Languages 2005. National Indigenous Languages Survey Report 2005, Commonwealth of Australia, Canberra.

Altman, J.C. 2007. 'Alleviating poverty in remote Indigenous Australia: The role of the hybrid economy', CAEPR Topical Issue, 10/2007, CAEPR, ANU, Canberra.

Appadurai, A. 1996. Modernity at Large: Cultural Dimensions of Globalization, University of Minnesota Press, Minneapolis.

Austin-Broos, D. 2003. 'Places, practices, and things: The articulation of Arrernte kinship with welfare and work', American Ethnologist, 30 (1): 118-35.

Baker, M. and Sloan, J. 1995. 'Australia's National Training Reform Agenda: A question of policy?' Australian Economic Review, 28 (2): 80-6.

Barton, D., Hamilton, M. and Ivanic, R. (eds) 2000. Situated Literacies: Reading and Writing in Context, Routledge, London.

Bat, M. 2005. 'When you can't even buy a bedtime story', Ngoonjook: A Journal of Australian Indigenous Issues, 27: 43-61.

Beresford, Q. and Omaji, P. 1996. Rites of Passage: Aboriginal Youth, Crime and Justice, Fremantle Arts Centre Press, Perth.

Berger, P.L. and Luckmann, T. 1975 [1966]. The Social Construction of Reality: A Treatise in the Sociology of Knowledge, Penguin, Harmondsworth.

Bottrell, D. and Armstrong, D. 2007. 'Changes and exchanges in marginal youth transitions', Journal of Youth Studies, 10 (3): 353-71.

Bourdieu, P. 1977. Outline of a Theory of Practice, Cambridge University Press, Cambridge.

Brady, M. 1992. Heavy Metal: The Social Meaning of Petrol Sniffing in Australia, Aboriginal Studies Press, Canberra.

Brooks, D. forthcoming. 'Organization within disorder-The present and future of young people in the Ngaanyatjarra Lands', in U. Eickelkamp and P. Fietz (eds), Youngfella World: Indigenous Experiences of Childhood and Youth in Central Australia, Berghahn Books, Oxford.

Burbank, V. 2006. 'From bedtime to on time: Why many Aboriginal people don't especially like participating in Western institutions', Anthropological Forum, 16 (1): 3-20.

Burton, L. M., Obeidallah, D. A. and Allison, K. 1996. 'Ethnographic insights on social context and adolescent development among inner-city African-American teens', in R. Jessor, A. Colby and R. A. Shweder (eds), Ethnography and Human Development: Context and Meaning in Social Inquiry, The University of Chicago Press, Chicago and London, pp. 395-418.

de Certeau, M. 1984. The Practice of Everyday Life, University of California Press, Berkeley.

Commonwealth of Australia 2008. Increasing Indigenous Employment Opportunity: A Discussion Paper on Proposed Reforms to the CDEP and Indigenous Employment Programs 2008, Australian Government, Canberra.

Coombs, H.C. 1977. The Application of CDEP in Aboriginal Communities in the Eastern Zone of Western Australia, CRES Working Paper HCC/3: 1977, ANU, Canberra.

Davenport, S., Johnson, P. and Yuwali 2005. Cleared Out: First Contact in the Western Desert, Aboriginal Studies Press, Canberra. 
Erickson, E. 1968. Identity: Youth and Crisis, Norton, New York.

Fietz, P. 2008. 'Socialisation and the shaping of youth identity at Docker River', in G. Robinson, U. Eickelkamp, J. Goodnow and I. Katz (eds), Contexts of Child Development: Culture, Policy and Intervention, Charles Darwin University Press, Darwin, pp. 49-58.

Fine, M., Weis, L., Centrie, C. and Roberts, R. 2000. 'Educating beyond the borders of schooling', Anthropology \& Education Quarterly, 31 (2): 131-51.

Gee, J.P. 2004. Situated Language and Learning: A Critique of Traditional Schooling, Routledge, New York.

Gibson, J. 2007. 'People, place and community memory: creating digital heritage databases in remote Aboriginal communities', Paper presented to Initiatives, Ideas And Interaction: Sharing Our Story Conference, Australian Society of Archivists Inc., Alice Springs.

Giddens, A. 1991. Modernity and Self-Identity: Self and Society in the Late Modern Age, Polity Press, Cambridge.

Heath, S.B. and Smyth, L. 1999. ArtShow: Youth and Community Development. A Resource Guide, Partners for a Livable Community, Washington.

Hull, G. 2003. 'At last. Youth culture and digital media: New literacies for new times', Research in the Teaching of English, 38 (2): 229-33.

— and Schultz, K. (eds) 2002. School's Out! Bridging Out-of-School Literacies with Classroom Practice, Teachers College Press, Colombia University New York.

James, T. 1993. 'The winnowing of organizations', in S.B. Heath and M.W. McLaughlin (eds), Identity and Inner-City Youth: Beyond Ethnicity and Gender, Teachers College Press, Colombia University New York.

Kral, I. 2007a. Literacy and Social Practice in the Remote Indigenous Context, Northern Territory Library, Darwin, unpublished manuscript available at <http://www.ntl.nt.gov.au/news/events/lunchtime_talks/2007/august_2008>.

— 2007b. Writing Words-Right Way! Literacy and Social Practice in the Ngaanyatjarra World, PhD thesis, The Australian National University, Canberra.

— and Falk, I. 2004. What is All That Learning For? Indigenous Adult English Literacy Practices, Training, Community Capacity and Health, NCVER, Adelaide.

Kress, G. 2003. Literacy in the New Media Age, Routledge, London.

Lave, J. and Wenger, E. 1991. Situated Learning: Legitimate Peripheral Participation, Cambridge University Press, Cambridge.

Mannheim, K. 1952. 'The problem of generations', in K. Mannheim (ed.), Essays on the Sociology of Knowledge, Routledge and Kegan Paul, London.

McLaughlin, M.W., Irby, M.A. and Langman, J. 1994. Urban Sanctuaries: Neighborhood Organizations in the Lives and Futures of Inner-City Youth, Jossey-Bass Publishers, San Francisco.

Mead, M. 1978 [1970]. Culture and Commitment: The New Relationships Between the Generations in the 1970s, Columbia University Press, New York.

Merlan, F. 1998. Caging the Rainbow: Places, Politics and Aborigines in a North Australian Town, University of Hawai'i Press, Honolulu.

Myers, F.R. 1986. Pintupi Country, Pintupi Self: Sentiment, Place and Politics Among Western Desert Aborigines, University of California Press, Berkeley. 
National Languages and Literacy Institute of Australia 1996. Desert Schools: An Investigation of English Language and literacy Among Young Aboriginal People in Seven Communities. (Volumes 1, 2 and 3), DEETYA and NLLIA South Australian Teaching and Curriculum Centre, Canberra.

Northern Territory Library 2008. The Walk to School: An Indigenous Early Years Literacy Strategy for the Northern Territory Public Libraries and Knowledge Centres, Northern Territory Library, Darwin.

Ochs, E. 1993. 'Constructing social identity: A language socialization perspective', Research on Language and Social Interaction, 26 (3): 287-306.

Ortner, S.B. 1984. 'Theory in anthropology since the Sixties', Comparative Studies in Society and History, 26: 126-66.

Pearson, N. 2000. Our Right to Take Responsibility, Noel Pearson and Associates, Cairns:.

Robinson, G. 1997. 'Trouble lines: Resistance, externalisation and individuation', Social Analysis, 41 (2): 122-54.

Rogoff, B. 2003. The Cultural Nature of Human Development, Oxford University Press, Oxford.

Rowse, T. 1998. White Flour, White Power: From Rations to Citizenship in Central Australia, Cambridge University Press, Cambridge.

Sanders, W.G. 1986. Access, Administration and Politics: The Australian Social Security System and Aborigines, PhD thesis, ANU, Canberra.

Smyth, J. and Hattam, R. 2004. 'Dropping Out', Drifting Off, Being Excluded: Becoming Somebody Without School, Peter Lang, New York.

Stanton, J. 1983. 'Old business, new owners: Succession and 'the Law' on the fringe of the Western Desert', in N. Peterson and M. Langton (eds), Aborigines, Land and Land Rights, Australian Institute of Aboriginal Studies, Canberra.

Street, B. V. (Ed.). 1993. Cross-Cultural Approaches to Literacy, Cambridge University Press, Cambridge.

von Sturmer, J. 1984. 'The different domains', in Australian Institute of Aboriginal Studies, Uranium Impact Project Steering Committee, Aborigines and uranium: Consolidated report on the social impact of uranium mining on the Aborigines of the Northern Territory, Canberra: AIAS, pp. 218-37.

Tonkinson, R. 1974. The Jigalong Mob: Aboriginal Victors of the Desert Crusade, Cummings, Menlo Park.

Vadeboncoeur, J.A. 2006. 'Engaging young people: Learning in informal contexts', Review of Research in Education, 30: 239-278.

Willis, P. 1977. Learning to Labour: How Working Class Kids Get Working Class Jobs, Saxon House, Westmead. 